\title{
Studi Salinitas Air Terhadap Penyerapan Logam Berat Merkuri Oleh Ikan Mujair (Tilapia mosambicca)
}

\author{
Titiek Sumarawati
}

\author{
Bagian Kimia, Fakultas Kedokteran Universitas Islam Sultan Agung \\ Jalan Raya kaligawe km. 4.Semarang
}

\begin{abstract}
Abstrak
Merkuri adalah logam berat yang toksik dalam jumlah kecil, akan tetapi toksisitasnya bervariasi tergantung dari bentuk senyawa kimianya dan tempat pemaparannya. Dalam perairan, kandungan logam merkuri sekalipun kadarnya relatif rendah, dapat diabsorbsi dan terakumulasi secara biologis oleh ikan dan akan terlibat dalam sistim jaringan makanan .

Pengamatan penelitian ini melihat kondisi air tambak oso yang meliputi suhu, $\mathrm{pH}$, salinitas, kandungan merkuri dalam air dan kandungan merkuri dalam ikan mujair. Jenis penelitian ini adalah penelitian analitik yang bersifat observasional, yang dilakukan secara cross-sectional.

Hasil dari penelitian ini menunjukkan bahwa kandungan logam merkuri dalam air rata rata sebesar $0,0024 \mathrm{ppm}$, dimana suhu berfluktasi, $\mathrm{pH}$ dan salinitas adalah relatif rendah. Rata rata suhu dari air $28,23^{\circ} \mathrm{C}, \mathrm{pH} 7,28$ dan salinitas $0,3084 \mathrm{o} / \mathrm{ooo}$. Merkuri dalam sampel ikan mujair rata-rata sebesar 0,00084 ppm. Sampel ikan mujair yang berumur 3 bulan. 4 bulan dan 5 bulan mempunyai kandungan merkuri yang berbeda.
\end{abstract}

(kata kunci : Absorbsi, Akumulasi, kandungan merkuri,, keracunan merkuri.)

\section{Abstract}

Mercury is a toxic heavy metal in a little number, but it's toxicitas is in variety of number depend on it's chemical compound form and the area of it's exposure. In the water, mercury is easily absorbed and accumulated in the tissues of the fish, and through food chains reaches the human body.

This research is conducted to find out the condition of Tambak oso river. The observation includes the water temperature, $\mathrm{pH}$, Salinity, checking mercury contents in the water, and checking of mercury contents in Tilapia mosambicca in the river.. This research used analytic observational approach and carried out in cross-sectional way.

The result of the study was that the mercurry level of the water was at the average of 0,0024 $\mathrm{ppm}$, the temperature fluctuated, $\mathrm{pH}$ and salinity are relatively low. The averagte temperature of the water was $28,23^{\circ} \mathrm{C}$, pH 7,28 and Salinity of the water was $0,3084 \mathrm{o} / \mathrm{ooo}$. The degree of mercury in the sample of mujair was at the average of $0,00084 \mathrm{ppm}$. It was indicated that there was diffrerent content of mercury in the three, four and five months of the sample of mujair .

(Key words : absorbtion, be accumulatted, mercury content, mercury toxic)

\section{PENDAHULUAN}

Pembangunan pada hakekatnya merupakan upaya manusia untuk mendapatkan suatu perikehidupan yang lebih baik . Pertumbuhan pembangunan nasional, dimasa kini dan mendatang akan diwarnai oleh 
perkembangan sarana dan prasarana yang demikian pesat, terutama disektor industri. Masyarakat industri pada umumnya hanya berorientasi pada ekonomi semata, terutama mencari keuntungan sebesar besarnya dan biaya operasional sekecil kecilnya, tidak jarang pabrik pabrik membuang limbahnya begitu saja ke badan badan air disekitarnya.

Dalam penggunaan sehari-hari, manusia akan memasukkan tambahan garam mineral kedalam air bersih yang digunakannya, demikian juga halnya pada air bersih yang digunakan pada proses industri. Penambahan kadar garam ini akan meningkatkan salinitas air. Dengan demikian salinitas air limbah cenderung lebih tinggi daripada salinitas air bersih. Selain salinitas meningkat dalam air limbah juga akan terkandung beberapa unsur yang tidak diharapkan keberadaannya di dalam suatu badan air. Salah satunya yaitu merkuri.

Penggunaan merkuri di industri industri makin meningkat baik sebagai zat pembantu proses maupun produksi hasil buangan dari suatu proses, Selain itu merkuri yang banyak kegunaannya baik untuk pertambangan maupun dibidang pertanian.

Akhir akhir ini di Indonesia keberadaan merkuri di dalam badan air sudah mulai dibicarakan. Dari penelitian yang telah dilakukan oleh Fuad Amsyari dkk, tahun1982 dikatakan konsentrasi rata rata merkuri $0,74 \mathrm{ppm}$ yang terkandung dalam ikan bader dan keting yang diambil dari kali Surabaya. Konsentrasi merkuri ini sudah lebih tinggi dari ambang batas yang ditetapkan FAO untuk kadar merkuri pada ikan yang boleh dikomsumsi manusia. Pada tahun 1984, Fuad Amsyari dkk melakukan penelitian kadar merkuri pada penduduk Surabaya, hasilnya menunjukkan bahwa merkuri rata rata pada penduduk didaerah penelitian jauh lebih tinggi dibanding dengan kadar merkuri rambut rata rata di Jakarta yakni 10,71 ppm.

Diantara kawasan kawasan industri yang ada di wilayah Surabaya, yaitu kawasan industri Rungkut Surabaya dimana kali tambak oso berada di wilayah tersebut, yang merupakan tempat pembuangan air limbah yang telah diolah terlebih dahulu oleh pabrik. Dari sini timbul permasalahan yang mendorong untuk dilakukan penelitian ini, mengingat lokasi berada disekeliling pabrik dan juga dimungkinkan kurangnya tingkat kesempurnaan pengolahan limbah yang dibuang oleh pabrik, sehingga dikhawatirkan masih terdapat kandungan logam merkuri, mengingat logam merkuri sukar mengalami proses pelapukan, baik secara kimia, fisika maupun biologi. Dengan melalui proses bioakumulasi maka dimungkinkan terjadinya keracunan merkuri pada mereka yang mengkonsumsi ikan yang telah mengandung merkuri.

Sifat kimia dan fisik merkuri yaitu merupakan logam berat yang terbentuk cair pada suhu kamar, 
dengan berat jenis 13,6 , berat atom 200,61 , titik beku $38,87^{\circ} \mathrm{C}$ dan titik didibnya $35,6^{\circ} \mathrm{C}$ (Fairhall, 1957). Merkuri secara kimiawi ditemukan dalam beberapa bentuk antara lain dalam bentuk merkuri elemental, merkuri an-organik dan merkuri organik. (Jasmaini, 1990).

Sumber pencemaran merkuri, secara alamiah hanya ada sedikit merkuri pada kerak bumi. Kandungan merkuri berkisar antara $50-80 \mathrm{ppb}$ (Friberg, 1972). Selain itu sumber merkuri juga berasal dari limbah industri, pertanian, pertambangan, kesehatan/kedokteran, kosmetika.

Proses bioakumulasi didalam ikan, ada dua cara yaitu langsung dan tidak langsung. Kontaminasi langsung terjadi, bila ikan terkena dari air, lalu akan masuk kedalam peredaran darah melalui ingsang dan kulit. Sedangkan kontaminasi tidak langsung akan dialami bila merkuri terkandung dalam makanan akan masuk kedalam sistim peredaran darah. Selanjutnya merkuri tersebut masuk kedalam otak, hati otot dan ginjal. Melalui merkuri dikeluarkan dari tubuh ikan (Nriagu, 1983).

Menurut Bryan (1976). Besarnya penyerapan tergantung pada beberapa faktor yaitu salinitas air, temperatur air, pH air, kesadahan air, adanya logam lain misalnya selenium, adanya senyawwa kompleks lainnya, ukurran tubuh organisme hidup.

Baku mutu air di Indonesia menurut peraturan pemerintah Republik Indonesia nomor 20 tahun 1990, menetapkan kadar maksimum merkuri yang diperoleh menurut golonganya yaitu untuk golongan A maksimum merkuri $0,001 \mathrm{mg} / 1$; golongan B kadar maksimum merkuri $0,00 \mathrm{mg} / \mathrm{l}$; golongan $\mathrm{C}$ kadar maksimum 0,002 $\mathrm{mg} / 1$; golongan D kadar maksimum $0,005 \mathrm{mg} / \mathrm{l}$.

\section{METODE DAN BAHAN PENELITIAN}

Jenis penelitian adalah analitik yang bersifat observasional, yang dilakukan secara cross sectional. Lokasi penelitian kali tambak oso, terletak di kotamadya Surabaya, kecamatan rungkut, kelurahan kutisari.

Populasi penelitian ini meliputi air kali tambak oso dan ikan mujair didaerah studi. Sampel air diambil berdasarkan titik-titik dimana ditetapkan tiga titik, dengan prinsip titik titik ini mewakili area. Sedangkan sampel ikan diambil acak, dengan mengumakan metode Petersen untuk menentukan umur ikan yaitu dengan meniimbang beratnya, diukur panjangnya kemudian digolongkan umur ikan.

Analisa yang digumakan analisa variant satu arah, untuk melihat perbedaan rata rata antar waktu pengambilan sampel air terhadap kandungan merkuri dalam air tambak oso, suhu air tambak oso, pH air tambak oso dan salinitas air tambak oso. Disamping itu juga untuk melihat perbedaan rata rata umur ikan terhadap kandungan merkuri dalam ikan. 
Bahan kimia yang dipakai kristal dan larutan Potasium Permanganan, larutan asam nitrat, asam sulfat , larutan Hydroxylamine Hydroclorida, larutan stannous chlorida, larutan Perak nitrat dan heparin. Sedang peralatan yang digunakan Mercury Analyzer Coleman M.AS-50, pH meter digital, botol tenggelam, termometer air raksa GRDLabortherm, jerigen plastik, botol $B O D$, erlemeyer, pipet volumetrik, stringe steril, timbangan kasar dan meteran.

\section{HASIL PENELITIAN DAN PEMBAHASAN}

\section{Pemeriksaan air kolam}

Hasil pemeriksaan air kali tambak oso meliputi kandungan merkury, suhu air, pH air dan Salinitas dapat dilihat pada tabel 1 sampai dengan tabel 4 dibawa ini.

Apabila dilihat dari keseluruhan sampel maka didapat hasil rata rata sebesar 0,0024 ppm, dengan demikian kadar merkuri dalam airkali tambak oso telah melebiha syarat baku mutu badan air golongan $\mathrm{C}$ (menurut peraturan pemerintah nomor 20 tahun 1990). Dengan analisa varian, menunjukkan tidak ada perbedaan yang bermakna sampai harga $p=0,103$ berarti selama tanggal pengambilan konsentrasi merkuri dalam air tidak mengalami perubahan.

Tabel 1 : Kadar merkuri (ppm) air kali tambak oso

\begin{tabular}{|c|c|c|c|c|}
\hline & & Tanggal & Pengambilan & \\
\hline No. & Minggu I & Minggu II & Minggu III & Minggu IV \\
\hline 1. & 0,0027 & 0,0007 & 0,0069 & 0,0032 \\
\hline 2. & 0,0021 & 0,0003 & 0,0032 & 0,0052 \\
\hline 3. & 0,0023 & 0,0012 & 0,0011 & 0,0026 \\
\hline 4. & 0,0031 & 0,0017 & 0,0009 & 0,0007 \\
\hline 5. & 0,0017 & 0,0001 & 0,0017 & 0,0061 \\
\hline 6. & 0,0009 & 0,0009 & 0,0021 & 0,0017 \\
\hline 7. & 0,0004 & 0,0031 & 0,0067 & 0,0017 \\
\hline 8. & 0,0037 & 0,0005 & 0,0083 & 0,0014 \\
\hline 9. & 0,0021 & 0,0027 & 0,0012 & 0,0027 \\
\hline 10. & 0,0012 & 0,0019 & 0,0005 & 0,0039 \\
\hline $\mathbf{X}$ & 0,0020 & 0,0013 & 0,0003 & 0,0029 \\
\hline
\end{tabular}


Tabel 2: Suhu Air kali Tambak oso $\left({ }^{\circ} \mathrm{C}\right)$

\begin{tabular}{|c|c|c|c|c|}
\hline & \multicolumn{2}{|r|}{ Tanggal } & \multicolumn{2}{|l|}{ Pengambilan } \\
\hline No. & Minggu I & Minggu II & Minggu III & Minggu IV \\
\hline 1. & 28,0 & 28,0 & 28,5 & 27,5 \\
\hline 2. & 28,0 & 27,0 & 28,5 & 28,0 \\
\hline 3. & 28,5 & 28,0 & 28,5 & 28,0 \\
\hline 4. & 28,0 & 28,0 & 28,0 & 28,0 \\
\hline 5. & 28,5 & 28,0 & 28,0 & 28,5 \\
\hline 6. & 28,5 & 28,0 & 28,0 & 29,0 \\
\hline 7. & 28,5 & 28,0 & 28,0 & 28,0 \\
\hline 8. & 28,5 & 28,0 & 28,5 & 28,5 \\
\hline 9. & 28,5 & 28,0 & 28,5 & 28,0 \\
\hline 10. & 28,5 & 28,0 & 28,5 & 28,5 \\
\hline$\overline{\mathbf{x}}$ & 28,35 & 27,95 & 28,40 & 28,20 \\
\hline
\end{tabular}

Dengan analisa varian, menunjukkan ada perbedaan bermakna sampai harga $\mathrm{p}=0,00086$. Menurut Gavis dan Ferguson (1972), dikatakan bahwa suhu dapat menyebabkan terjadinya peningkatan kelarutan logam berat dalam air. Hal ini meningkatkan terjadinya peningkatan akumulasi logam tersebut pada tubuh organisme air. Jika dilihat tabel diatas, didapat gambaran bahwa suatu saat terjadi penurunan suhu dan pada saat yang lain kembali terjadi penurunan suhu danpada saat yang lain kembali terjadi peningkatan yang kecil. Keadaan suhu air tambak oso ini masih dalam . kondisi normal antara $27^{\circ} \mathrm{C}-29^{\circ} \mathrm{C}$, sehingga pengaruh terhadap kadar merkuri fluktuasi sangat rendah.

Tabel 3: pH air tambak oso

\begin{tabular}{|c|c|c|c|c|}
\hline & \multicolumn{5}{|c|}{ Tanggal } & \multicolumn{2}{c|}{ Pengambilan } \\
\hline No. & Minggu I & Minggu II & Minggu III & Minggu IV \\
\hline 1. & 7,2 & 7,0 & 7,3 & 7,7 \\
2. & 7,4 & 7,1 & 7,1 & 7,5 \\
3. & 7,3 & 7,2 & 7,4 & 7,4 \\
4. & 7,2 & 7,0 & 7,2 & 7,6 \\
5. & 7,3 & 7,0 & 7,1 & 7,4 \\
6. & 7,4 & 7,2 & 7,2 & 7,5 \\
7. & 7,3 & 7,1 & 7,4 & 7,4 \\
8. & 7,2 & 7,0 & 7,3 & 7,5 \\
9. & 7,2 & 7,1 & 7,1 & 7,6 \\
10. & 7,2 & 7,0 & 7,1 & 7,7 \\
\hline $\overrightarrow{\mathbf{x}}$ & $\mathbf{7 , 3 1}$ & $\mathbf{7 , 0 7}$ & $\mathbf{7 , 2 2}$ & $\mathbf{7 , 5 3}$ \\
\hline
\end{tabular}


Kondisi asam basa air tambak oso selama penelitian yakni satu bulan, fluktuasinya rendah, terlihat pada tabel tersebut diatas. Dimana dengan perhitungan analisa varian perbedaan rata rata setiap minggunya selama penelitan berlangsung menunjukkan adanya perbedaan yang bermakna sampai harga $\mathrm{p}<0,01$. Perubahan $\mathrm{pH}$ ini masih dalam rentang kondisi normal yaitu $\mathrm{pH} 7,0$ - 7,5. $\mathrm{PH}$ kaitannya sangat penting dengan asam basa air, yang mana akan mempengaruhi kereaktifan merkuri.

Pada tabel 4 terlihat bahwa pengukuran salinitas setiap tanggal pengambilan sampel air dengan melalui perhitungan analisa varian, menunjukkan adanya perbedaan yang bermakna sampai harga $\mathrm{p}<0,01$

Tabel 4 : Salinitas air tambak oso (o/o0o )

\begin{tabular}{|c|c|c|c|c|}
\hline & & Tanggal & Pengambilan & \\
\hline No. & Minggu I & Minggu II & Minggu III & Minggu IV \\
\hline 1. & 0,250 & 0,377 & 0,270 & 0,389 \\
\hline 2. & 0,250 & 0,374 & 0,250 & 0,371 \\
\hline 3. & 0,240 & 0,371 & 0,280 & 0,321 \\
\hline 4. & 0,240 & 0,389 & 0,526 & 0,320 \\
\hline 5. & 0,250 & 0,374 & 0,271 & 0,291 \\
\hline 6. & 0,280 & 0,375 & $0,290^{\circ}$ & 0,287 \\
\hline 7. & 0,240 & 0,395 & 0,280 & 0,320 \\
\hline 8. & 0,280 & 0,371 & 0,240 & 0,280 \\
\hline 9. & 0,280 & 0,373 & 0,256 & 0,290 \\
\hline 10. & 0,280 & 0,389 & 0,270 & 0,280 \\
\hline$\vec{x}$ & 0,2590 & 0,3788 & 0,2663 & 0,3149 \\
\hline
\end{tabular}

Salinitas merupakan salah satu faktor yang menentukan besarnya penyerapan merkuri dalam ikan , penyerapan merkuri cenderung berkurang dengan bertambahnya salinitas air (Bryanm 1976). Dari sampel keseluruhan hasil rata rata salinitas 0,3048 o/ooo dapat dikategorikan sedang. Untuk jenis salinitas air sedang, ikan cukup tahan (tidak mati) terhadap adanya merkuri di dalam air.

\section{Hasil 'pemeriksaan kadar merkuri dalam ikan mujair}

Sesuai dengan hasil pemeriksaan air tambak oso mengandung merkuri maka melalui rantai makanan, logam berat merkuri yang terdapat dalam air 
tambak oso akan diabsorbsi dan terakumulasi dalam tubuh ikan sehingga ikan mujair yang hidup di air tambak oso mengandung merkuri. Mengingat ikan mujair makanannya terdiri dari segala macam dimakan atau dapat dikatakan ikan yang paling rakus. Ukuran tubuh organisme juga mempengaruhi besarnya konsentrasi merkuri yang terkandug dalam organisme tersebut (Wilbert, 1969). Hal ini memperiihatkan suatu hubungan antara konsentrasi dan lamanya hidup.

Dari tabel tersebut dibawah dapat dilihat bahwa konsentrasi untuk masing masing ikan mujair umur 3 bulan, 4 bulan dan 5 bulan masih memenuhi standard yang ditentukan baik menurut EPA maupun Departemen Kesehatan Republik Indonesia yaitu batas maksimum kandungan merkuri dalam makanan yang masih dapat dikonsumsi sebesar $0,5 \mathrm{ppm}$.

Tabel 5:

Kadar merkuri (ppm) pada ikan mujair

umur 3 bulan, 4 bulan, 5 bulan di air Tambak oso

\begin{tabular}{|c|c|c|c|c|}
\hline \multirow[b]{2}{*}{ No } & \multirow[b]{2}{*}{ Saat Pengambilan } & \multicolumn{3}{|c|}{ Umur Ikan Mujair } \\
\hline & & 3 bulan & 4 bulan & 5 bulan \\
\hline $\begin{array}{l}1 \\
2 \\
3\end{array}$ & Minggu I & $\begin{array}{l}0,00021 \\
0,00014 \\
0,00070 \\
X=0,0005\end{array}$ & $\begin{array}{l}0,00026 \\
0,00041 \\
0,00017 \\
X=0,00028\end{array}$ & $\begin{array}{l}0.00190 \\
0,00031 \\
0,00110 \\
X=0,00110\end{array}$ \\
\hline $\begin{array}{l}4 \\
5\end{array}$ & Minggu II & $\begin{array}{l}0,00010 \\
0,00060 \\
X=0,00035\end{array}$ & $\begin{array}{l}0,00080 \\
0,00019 \\
X=0,00050\end{array}$ & $\begin{array}{l}0,00080 \\
0,00040 \\
X=0,00060\end{array}$ \\
\hline $\begin{array}{l}6 \\
7\end{array}$ & Minggu III & $\begin{array}{l}0,00011 \\
0,00040 \\
X=0,00026\end{array}$ & $\begin{array}{l}0,00017 \\
0,00020 \\
X=0,00019\end{array}$ & $\begin{array}{l}0,00210 \\
0,00300 \\
X=0,00260 \\
\end{array}$ \\
\hline $\begin{array}{l}8 \\
9 \\
10\end{array}$ & Minggu IV & $\begin{array}{l}0,00012 \\
0,00026 \\
0,00030 \\
X=0,00023\end{array}$ & $\begin{array}{l}0,00140 \\
0,00260 \\
0,00310 \\
X=0,00240\end{array}$ & $\begin{array}{l}0,00050 \\
0,00270 \\
0,00037 \\
X=0,00120\end{array}$ \\
\hline
\end{tabular}

Dengan perhitungan analisa varian, menunjukkan bahwa ada perbedaan yang bermakna sampai harga $\mathrm{p}=0,04$, dengan demikian kadar merkuri yang ada dalam ikan mujair umur $S$ bulan, kadar merkuri rata rata $0,0013 \mathrm{ppm}$ 
lebih besar dibanding ikan mujair umur 4 bulan dengan kadar merkuri rata rata $0,0009 \mathrm{ppm}$. Sedangkan ikan mujair umur 3 bulan kadar merkuri rata rata $0,00029 \mathrm{ppm}$. Tetapi jika dilihat antara saat pengambilan sampel dan umur ikan mujair terhadap kandungan merkuri pada ikan mujair, maka dapat dikatakan bahwa umur ikan dan waktu pengambilan tidak menunjukkan ada perbedaan yang bermakna.

\section{KESIMPULAN}

Hasil-hasil yang diperoleh dari pembahasan maka dapat disimpulkan sebagai berikut

1. Air tambak oso dari sampel keseluruhan didapat hasil rata rata untuk suhu air tambak oso adalah $28,23^{\circ} \mathrm{C}$; untuk pH adalah sebesar 7,228 dan untuk salinitas sebesar sebesar 0,3048 o/ooo. Sedang kadar merkuri di air tambak oso, dari keseluruhan didapat hasil rata rata sebesar $0,0024 \mathrm{ppm}$, hasil ini menunjukkan bahwa kandungan merkuri yang ada di air tambak oso sudah diatas ambang batas kadar maksimum merkuri yang diperbolehkan untuk badan air golongan $\mathrm{C}$ (untuk perikanan) menurut Peraturan Pemerintahan nomor 20 /tahun 1990.

2. Sampel ikan mujair dari keseluruhan sampel, didapat hasil rata rata kadar merkuri adalah sebesar 0,00084 ppm. Hasil rata rata kadar logam berat merkuri ini menunjukkan masih dalam ketentuan standart kadar merkuri yang diperkenankan pada makanan, yaitu sebesar $0,5 \mathrm{ppm}$ ditetapkan oleh WHO. Kandungan logam berat merkuri yang ada dalam ikan mujair yang berumur lebih tua mengakumulasinya lebih banyak dibanding ikan mujair yang berumur lebih muda.

\section{DAFTAR PUSTAKA}

Amsyari, Fuad.dkk, 1982. Kadar merkuri,Cuprum dan Cadmium pada ikan bader dan ikan keting di Perairan kali Surabaya, Unit Kesehatan Lingkungan Hidup. Fak. Kedokteran Unair. Surabaya.

Amsyari, Fuad.dkk, 1984. Penelitian Kadar merkuri Penduduk Surabaya Jawa Timur. Fak. Kedokteran Unair, Surabaya.

Bryan,G.W. 1976. Some Aspects of Heavy Metal Tolerance in Aquatic Efects of Pollutants on aquatic Organisme. London Cambridge University Press.

Buttlet, G.C.ed. 1976. Principles of ecotoxicology Scope 1. New Yrk. John Wiley \& Sons.

Fairhall dkk, 1957. Industrial Toxycology. Baltimore, the Williams dan Wikins Co.

French, Richard H. 1984. Salinity in watercourses and Reservoirs. USA, Butterworth Publishers. 
Friberg dkk, 1972. Mercury in the Environment. Ohio, CRC Press.

Gerlach dkk, 1981. A Marine Pollution. New York. Springer-verlag. Jasmaini, 1990. Pengaruh pencemaran merkuri terhadap kesehatan. Majalah Kesehatan Masyarakat Indonesia. Tahun XIX no.2. Jakarta.

Nazir Moh, 1985, Metode Penelitian. Ghalia Indonesia. Jakarta.

Nriagu, Jerome E ed. 1983. Aquatic Toxicology. Canada. John Wiley \& Sons.

Peraturan Pemerintah Republik Indonesia nomor 20/tahun 1990.

Surat Keputusan Gubernur Kepala Daerah Tingkat I Jawa Timur tahun1987.

Wilber, Charles G, 1969. The Biological Aspect of Water Pollution USA. Charles C. Thomas Pub.

World Health Organization, 1980. Techinical Report Series. Genewa. No.647.

World Health Organization, 1972. Health Hazard of human enviromental Genewa WHO.

World Health Organization, 1989. Mercury Enviromental Aspects. Genewa WHO. 